Article

\title{
An Ultrasonication-Assisted Cobalt Hydroxide Composite with Enhanced Electrocatalytic Activity toward Oxygen Evolution Reaction
}

\author{
Yujun Si ${ }^{1, *}$, Chaozhong Guo ${ }^{2, *}$, Chenglong Xie ${ }^{1}$ and Zhongping Xiong ${ }^{1}$ \\ 1 College of Chemistry and Environmental Engineering, Sichuan University of Science and Engineering, \\ Zigong 643000, China; 13438027021@163.com (C.X.); xiongzhongp@163.com (Z.X.) \\ 2 Research Institute for New Materials Technology, Engineering Research Center of New Energy Storage \\ Devices and Applications, Chongqing University of Arts and Sciences, Chongqing 402160, China \\ * Correspondence: syj08448@163.com (Y.S.); guochaozhong1987@163.com (C.G.)
}

Received: 11 August 2018; Accepted: 29 September 2018; Published: 9 October 2018

\begin{abstract}
A catalyst toward oxygen evolution reaction (OER) was synthesized by depositing cobalt hydroxide on carbon black. Ultrasonication was applied during precipitation to improve the performance of the catalyst. The ultrasonic-assisted process resulted in the refinement of the cobalt hydroxide particles from $400 \mathrm{~nm}$ to $50 \mathrm{~nm}$, and the thorough incorporation of these particles with carbon black substrate. The resulting product exhibited enhanced OER catalytic activity with an onset potential of $1.54 \mathrm{~V}$ (vs. reversible hydrogen electrode), a Tafel slope of $18.18 \mathrm{mV} / \mathrm{dec}$, and a stable OER potential at a current density of $10 \mathrm{~mA} \mathrm{~cm}^{-2}$, because of the reduced resistance of the catalyst and the electron transfer resistance.
\end{abstract}

Keywords: oxygen evolution reaction; electrocatalyst; cobalt hydroxide; ultrasonication assistance

\section{Introduction}

Clean and renewable energy sources are urgently needed to be developed to address the increasing energy crisis and pollution problems. Hydrogen, as a high-energy density noncarbon energy source, has been considered as a clean energy source, and its production has been one of the top research hotspots. Electrochemical water splitting is an effective approach to convert renewable energy sources to promising hydrogen energy [1-5]. This process involves a hydrogen evolution reaction at the cathode, and an oxygen evolution reaction (OER, $4 \mathrm{OH}^{-} \rightarrow \mathrm{O}_{2}+2 \mathrm{H}_{2} \mathrm{O}+4 \mathrm{e}^{-}$in alkaline solution) at the anode. The OER is the major obstacle for water splitting, because this process is kinetically sluggish, involving a complex four-electron transfer with high overpotential [6-8]. Considerable attention has been paid to developing efficient catalysts for OER with low overpotential and high activity.

$\mathrm{IrO}_{2}$ and $\mathrm{RuO}_{2}$ have been demonstrated as the best OER electrocatalysts $[9,10]$. However, their large-scale applications are blocked by their high prices and limited natural reserves. The first-row transition metal oxides have been extensively investigated because of their natural abundance, low cost, environmental-friendliness, and high catalytic activity [11-16]. Studies have suggested that the oxy-hydroxides of nickel, cobalt, and iron are promising electrocatalysts for the OER. $\mathrm{Co}_{3} \mathrm{O}_{4}$ [17-19] and $\mathrm{Co}(\mathrm{OH})_{2}$ [20-22], synthesized by different methods have been widely investigated because of their high stability and high catalytic activity (theoretically, $\mathrm{Co}_{3} \mathrm{O}_{4}$ can close the OER activity of $\mathrm{RuO}_{2}$ and $\mathrm{IrO}_{2}$ ). However, the development of oxy-hydroxides of cobalt with high electrocatalytic activity to OER remains a major challenge because of poor electrical conductivity and limited exposed active sites.

To obtain an OER catalyst with better conductivity, transition metal oxide catalysts are mixed with conductive materials, such as carbon black, with the aid of polymeric binders in actual application. 
However, the utilization of insulating binders can reduce the electrocatalytic performance [23,24]. An efficient strategy to overcome this shortage is by fabricating nanoparticles of OER catalysts and naturally immobilizing the nanoparticles onto the conductive substrates. Fabrication of composites of oxy-hydroxides of cobalt with functionalized carbon-based materials (e.g., heteroatom-doped graphene and carbon nanotubes) has received special interest. This process can improve the poor conductivity of metal oxides, and the resulting catalysts also usually exhibit bifunctional catalytic activities $[25,26]$. The morphologies of the transition metal oxides also play a key role in the heterogeneous electrocatalytic reaction, because more catalytic active sites can be exposed to facilitate the OER by refining the particle sizes or by increasing the porosity of the catalysts with greater specific surface area $[27,28]$.

Ultrasonication is a nonconventional technique that has been proven to be superior on operation, product selectivity, and reduced reaction time. Ultrasonication can bring instantaneous generation, and the growth and collapse of micrometer-sized bubbles in liquid medium, which is helpful for the synthesis of nanostructured materials. Recently, the use of ultrasonication in chemistry has grown significantly [29-31]. In the present work, we prepared cobalt hydroxide $\left[\mathrm{Co}(\mathrm{OH})_{2}\right]$ by parallel flow precipitation on carbon black with the assistance of ultrasonication. The particles of $\mathrm{Co}(\mathrm{OH})_{2}$ were refined and well incorporated with the carbon black substrate, and the resulting catalyst shows enhanced OER catalytic activity.

\section{Experimental}

\subsection{Synthesis of the Catalyst}

A mixed solvent ( $\mathrm{pH} 10)$ from $30 \mathrm{~mL}$ of deionized water and $30 \mathrm{~mL}$ of ethanol was placed in a water bath $\left(50^{\circ} \mathrm{C}\right)$ with an ultrasonic generator $(40 \mathrm{kHz})$. Then, $2 \mathrm{~g}$ of carbon black (VXC72R, Cabot) was dispersed into the solvent under ultrasonication and mechanical stirring. Afterward, $30 \mathrm{~mL}$ of $\mathrm{Co}\left(\mathrm{NO}_{3}\right)_{2} \cdot 6 \mathrm{H}_{2} \mathrm{O}$ solution $(1.0 \mathrm{~mol} \mathrm{~L}-1,0.03 \mathrm{~mol})$ and $30 \mathrm{~mL}$ of $\mathrm{KOH}$ solution $(2.0 \mathrm{~mol} \mathrm{~L}-1,0.06 \mathrm{~mol})$ were added into the mixed solvent at $1.0 \mathrm{~mL} \mathrm{~min}^{-1}$ by two peristaltic pumps. Then, ultrasonication and stirring were terminated, by keeping the reaction system in the water bath for another $10 \mathrm{~h}$, followed by filtering and washing with deionized water until $\mathrm{pH}$ 7, drying at $80^{\circ} \mathrm{C}$ for $10 \mathrm{~h}$. The resulting catalyst was denoted as ultra- $\mathrm{Co}(\mathrm{OH})_{2} / \mathrm{C}$. As a control, $\mathrm{Co}(\mathrm{OH})_{2} / \mathrm{C}$ was prepared by the same procedure but without the assistance of ultrasonication during precipitation.

\subsection{Physical Characterizations}

The phase structure of the catalyst was determined using an X-ray diffractometer (XRD) (DX-2600, Fangyuan, Dandong, China). The morphology was observed using scanning electron microscopy (SEM) (Gemini SEM 300, Zeiss, Oberkochen, Germany).

\subsection{Electrochemical Measurements}

The OER catalytic activity of the catalyst was evaluated by electrochemical measurements performed in $0.1 \mathrm{M} \mathrm{KOH}$ solution on a CHI760E workstation (Chenhua, Shanghai, China) with a platinum sheet as a counter-electrode, a saturated calomel electrode (SCE) as a reference electrode, and a glassy carbon electrode $(\Phi=0.5 \mathrm{~cm})$ coated with the catalyst as a working electrode by pipetting $10 \mu \mathrm{L}$ of dispersion of catalyst (including commercial $\mathrm{RuO}_{2}, 10 \mathrm{mg} \mathrm{mL}^{-1}$ of concentration) onto the electrode surface and naturally drying in air. The catalyst loading on the working electrode was $0.51 \mathrm{mg} \mathrm{cm}^{-2}$. Electrochemical linear sweep voltammetry (LSV) was conducted at a scan rate of $5 \mathrm{mV}$ $\mathrm{s}^{-1}$. The OER potential was recorded by chronopotentiometry at a current density of $10 \mathrm{~mA} \mathrm{~cm}{ }^{-2}$. The dispersion of catalyst was also dropped on graphite paper and carried out the chronopotentiometry test for $5 \mathrm{~h}$, and then its micromorphology was observed. The electrochemical impedance spectrum (EIS) was tested over a frequency range from $10^{5} \mathrm{~Hz}$ to $0.1 \mathrm{~Hz}$. All of the potentials were converted to reversible hydrogen electrode (RHE) using the equation $E_{\mathrm{RHE}}=E_{\mathrm{SCE}}+0.2415 \mathrm{~V}+0.0591 \mathrm{pH}(\mathrm{pH} 13)$. 


\section{Results and Discussion}

Figure 1 shows the preparation of the $\mathrm{Co}(\mathrm{OH})_{2} / \mathrm{C}$ catalysts without/with ultrasonication, and the morphologies of the resulting catalysts. Once the solutions of $\mathrm{Co}\left(\mathrm{NO}_{3}\right)_{2}$ and $\mathrm{KOH}$ were dropped into the suspension containing carbon black, the $\mathrm{Co}^{2+}$ ions immediately reacted with the $\mathrm{OH}^{-}$ions to form the $\mathrm{Co}(\mathrm{OH})_{2}$ precipitates. These precipitates were deposited onto the surface of carbon black to yield the $\mathrm{Co}(\mathrm{OH})_{2} / \mathrm{C}$ catalyst.

During the initial stage of precipitation, the $\mathrm{Co}(\mathrm{OH})_{2}$ particles were small and had greater surface Gibbs free energies. The particles spontaneously assembled to form bigger crystals under quiet conditions. However, crystal growth was destroyed once ultrasonication was imposed on the reaction system. The SEM images in Figure 1 show that the hexagonal crystals of $\mathrm{Co}(\mathrm{OH})_{2}$ with size of approximately $400 \mathrm{~nm}$ can be observed in the $\mathrm{Co}(\mathrm{OH})_{2} / \mathrm{C}$ catalyst. The $\mathrm{Co}(\mathrm{OH})_{2}$ particles were bigger than that of carbon black, and they were not well incorporated with each other. However, only spherical particles with sizes of less than $50 \mathrm{~nm}$ could be observed, and no obvious $\mathrm{Co}(\mathrm{OH})_{2}$ particles with regular shapes were found in the ultra- $\mathrm{Co}(\mathrm{OH})_{2} / \mathrm{C}$ prepared with the assistance of ultrasonication. The results indicate that $\mathrm{Co}(\mathrm{OH})_{2}$ crystal could not grow well because of the disturbance caused by ultrasonication during precipitation. The $\mathrm{Co}(\mathrm{OH})_{2}$ precipitates existed as small particles, and they were absorbed on the surface of carbon black. Thus, better distribution and incorporation with carbon black substrate was found in ultra- $\mathrm{Co}(\mathrm{OH})_{2} / \mathrm{C}$.

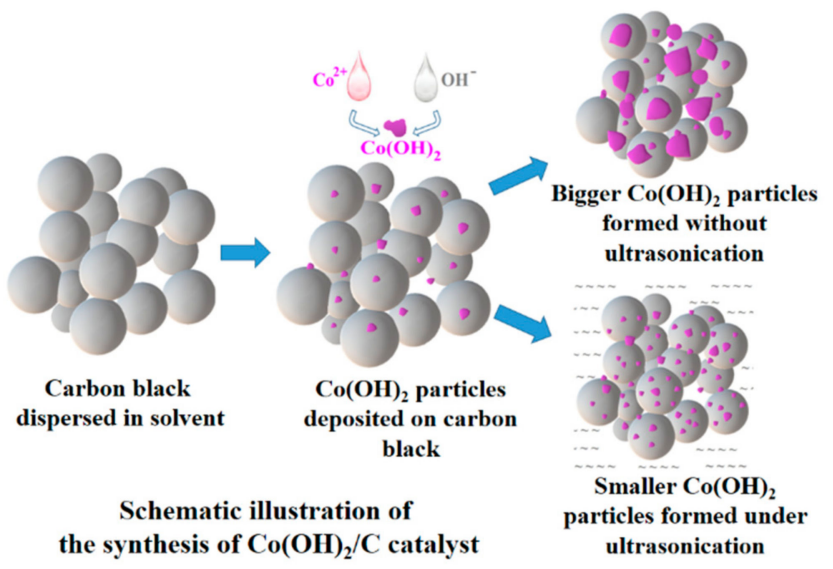

the synthesis of $\mathrm{Co}(\mathrm{OH})_{2} / \mathrm{C}$ catalyst

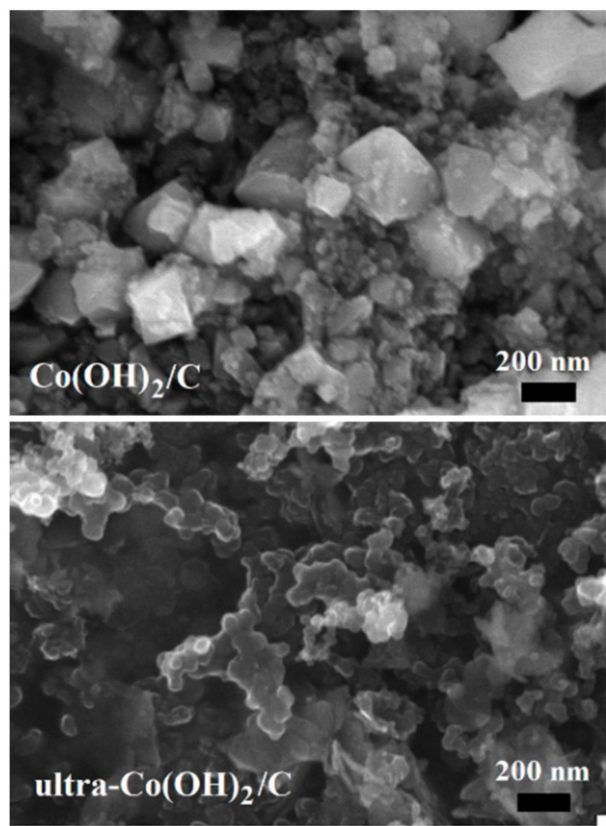

Figure 1. Fabrication of $\mathrm{Co}(\mathrm{OH})_{2} / \mathrm{C}$, ultra- $\mathrm{Co}(\mathrm{OH})_{2} / \mathrm{C}$ and the scanning electron microscopy (SEM) images of the catalysts.

Figure 2 shows the XRD patterns of $\mathrm{Co}(\mathrm{OH})_{2} / \mathrm{C}$ and ultra- $\mathrm{Co}(\mathrm{OH})_{2} / \mathrm{C}$. The cobalt element mainly existed as $\mathrm{Co}(\mathrm{OH})_{2}$ (JCPDS No. 30-0443) in the catalysts. The crystallite sizes of $\mathrm{Co}(\mathrm{OH})_{2}$ were calculated by the Scherrer Equation from three lattice planes (001), (100), and (101), and they were listed in the XRD patterns. Apparently, the crystallites were also refined by ultrasonication. 


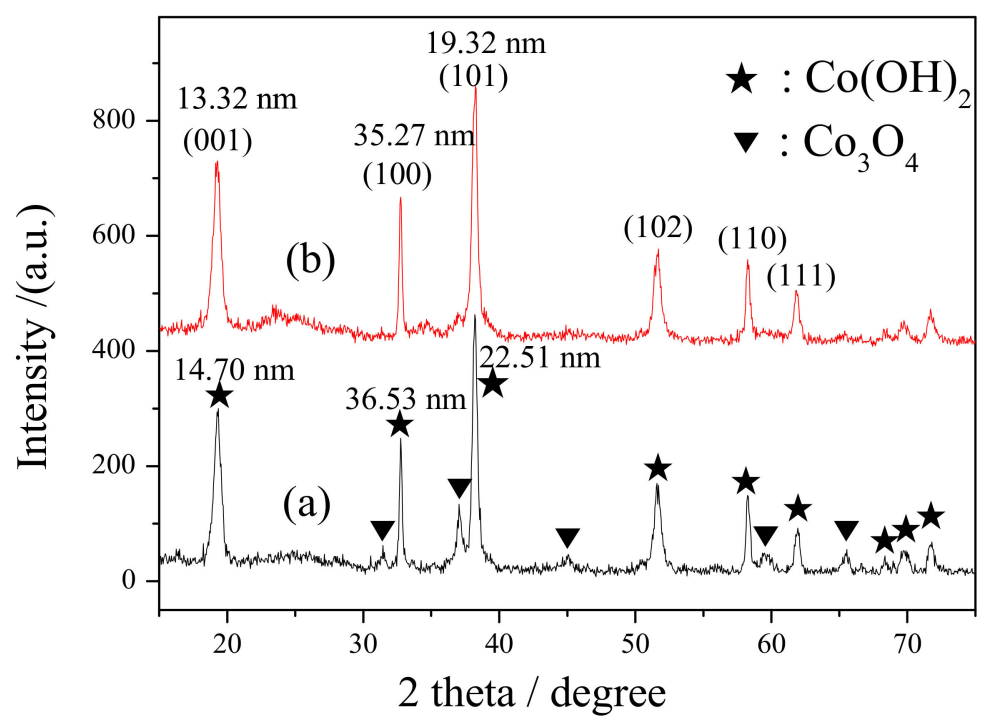

Figure 2. X-ray diffractometer $(\mathrm{XRD})$ patterns of the $(\mathbf{a}) \mathrm{Co}(\mathrm{OH})_{2} / \mathrm{C}$ and $(\mathbf{b})$ ultra- $\mathrm{Co}(\mathrm{OH})_{2} / \mathrm{C}$ catalysts.

The electrocatalytic performance of the catalysts to the OER was investigated in $0.1 \mathrm{M} \mathrm{KOH}$ solution. Figure 3a shows the linear sweep voltammetry (LSV) curves of the OER on the catalysts of $\mathrm{Co}(\mathrm{OH})_{2} / \mathrm{C}$, ultra-Co(OH) $)_{2} / \mathrm{C}$, and pure commercial $\mathrm{RuO}_{2}$. The OER onset potential of $\mathrm{RuO}_{2}$ was approximately $1.52 \mathrm{~V}$, while those of $\mathrm{Co}(\mathrm{OH})_{2} / \mathrm{C}$ and ultra- $\mathrm{Co}(\mathrm{OH})_{2} / \mathrm{C}$ were approximately $1.54 \mathrm{~V}$. The similar potentials show that the OER catalytic activity of $\mathrm{Co}(\mathrm{OH})_{2}$ was close to the OER activity of the benchmark $\mathrm{RuO}_{2}$ catalyst. However, the OER current densities of the three catalysts were different from each other. At the same potential of $1.66 \mathrm{~V}$, the OER current density was $6.16 \mathrm{~mA} \mathrm{~cm}^{-2}$ on the ultra- $\mathrm{Co}(\mathrm{OH})_{2} / \mathrm{C}$, which was greater than the $4.05 \mathrm{~mA} \mathrm{~cm}^{-2}$ of the $\mathrm{Co}(\mathrm{OH})_{2} / \mathrm{C}$ and the $2.95 \mathrm{~mA} \mathrm{~cm}^{-2}$ of $\mathrm{RuO}_{2}$. The improvement in catalytic performance of ultra- $\mathrm{Co}(\mathrm{OH})_{2} / \mathrm{C}$ can be attributed to its smaller particle size and better conductivity.

The LSV curves were converted to Tafel plots and fitted by the Tafel equation $(\eta=a+b \lg j$, where $\eta$ is the overpotential, $j$ is the current density, and $b$ is the Tafel slope) to examine the catalytic kinetics of the catalysts, as shown in Figure 3b. As expected, the ultra- $\mathrm{Co}(\mathrm{OH})_{2} / \mathrm{C}$ showed a Tafel slope of $18.18 \mathrm{mV} / \mathrm{dec}$, which was less than the $18.92 \mathrm{mV} / \mathrm{dec}$ of the $\mathrm{Co}(\mathrm{OH})_{2} / \mathrm{C}$ and $20.25 \mathrm{mV} / \mathrm{dec}$ of $\mathrm{RuO}_{2}$. Thus, the ultra- $\mathrm{Co}(\mathrm{OH})_{2} / \mathrm{C}$ could achieve higher current density at a lower overpotential than the $\mathrm{Co}(\mathrm{OH})_{2} / \mathrm{C}$ and $\mathrm{RuO}_{2}$ catalysts. Figure 4 presents the OER performed at $10 \mathrm{~mA} \mathrm{~cm}{ }^{-2}$ of current density, and the SEM imagines of the two catalysts after catalyzing OER for $5 \mathrm{~h}$. The electrode potential of ultra- $\mathrm{Co}(\mathrm{OH})_{2} / \mathrm{C}$ remained stable at a lower level in the OER process. However, the overpotential of $\mathrm{Co}(\mathrm{OH})_{2} / \mathrm{C}$ catalyst was greater, and it increased with the reaction time. As shown in the SEM images, the hexagonal crystals of $\mathrm{Co}(\mathrm{OH})_{2}$ in $\mathrm{Co}(\mathrm{OH})_{2} / \mathrm{C}$ catalyst disappeared after the OER. The broken crystals of $\mathrm{Co}(\mathrm{OH})_{2}$ in the OER process deteriorated the catalysis performance of the $\mathrm{Co}(\mathrm{OH})_{2} / \mathrm{C}$ catalyst.

These results indicate that the ultra- $\mathrm{Co}(\mathrm{OH})_{2} / \mathrm{C}$ catalyst has better OER catalytic performance than the $\mathrm{Co}(\mathrm{OH})_{2} / \mathrm{C}$ catalyst. This characteristic was due to the fact that the $\mathrm{Co}(\mathrm{OH})_{2}$ particles were smaller in the ultra- $\mathrm{Co}(\mathrm{OH})_{2} / \mathrm{C}$ catalyst than in the $\mathrm{Co}(\mathrm{OH})_{2} / \mathrm{C}$ catalyst without the disturbance from the ultrasonication during precipitation. Consequently, the $\mathrm{Co}(\mathrm{OH})_{2}$ in the ultra- $\mathrm{Co}(\mathrm{OH})_{2} / \mathrm{C}$ catalyst had a greater electrochemical specific surface area and more exposed active sites to catalyze the oxygen evolution reaction. 

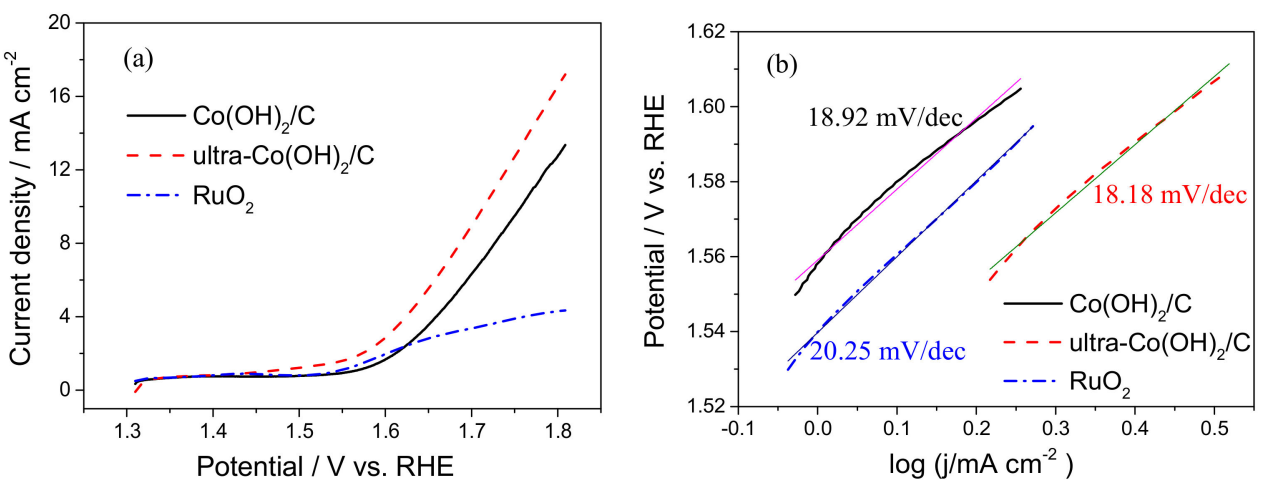

Figure 3. (a) Linear sweep voltammetry curves and (b) Tafel plots of ultra- $\mathrm{Co}(\mathrm{OH})_{2} / \mathrm{C}, \mathrm{Co}(\mathrm{OH})_{2} / \mathrm{C}$, and $\mathrm{RuO}_{2}$ catalysts in $0.1 \mathrm{M} \mathrm{KOH}$.
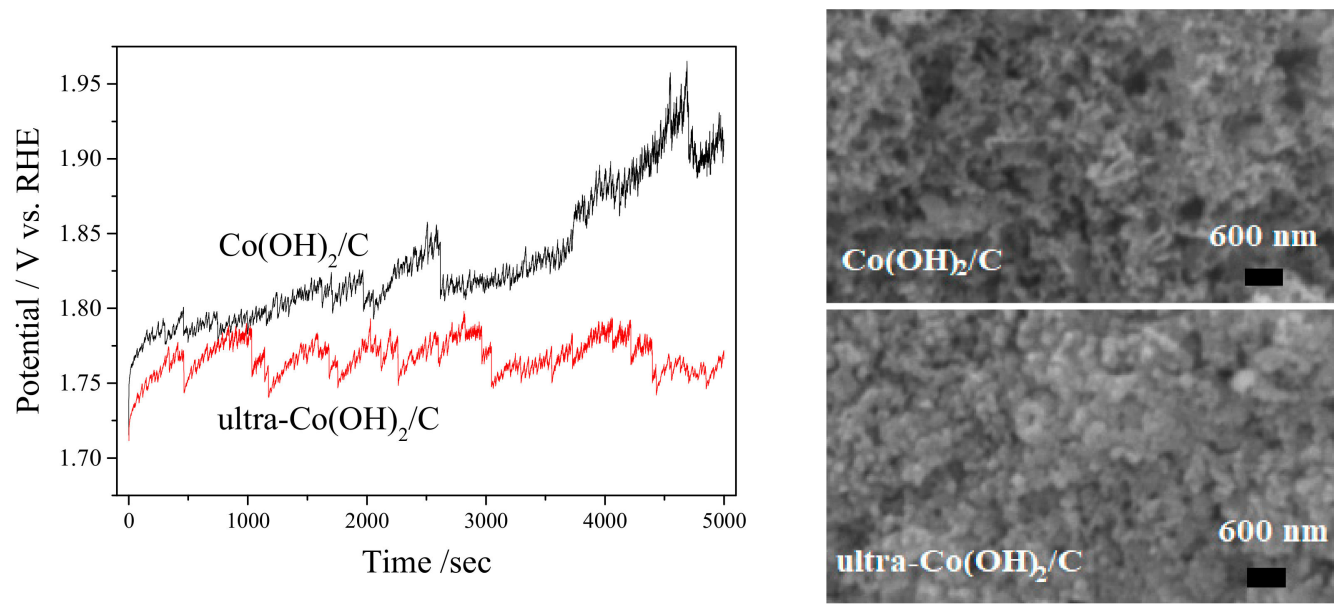

Figure 4. Chronopotentiometry curves of ultra- $\mathrm{Co}(\mathrm{OH})_{2} / \mathrm{C}$ and $\mathrm{Co}(\mathrm{OH})_{2} / \mathrm{C}$ catalysts at a current density of $10 \mathrm{~mA} \mathrm{~cm}^{-2}$ in $0.1 \mathrm{M} \mathrm{KOH}$, and SEM images after catalyzing OER for $5 \mathrm{~h}$.

To further investigate the charge transfer kinetics during the OER, electrochemical impedance spectroscopy (EIS) was performed at $1.66 \mathrm{~V}$ of potential, at which OER were catalyzed both on the two catalysts. Figure 5 a shows that the Nyquist curves of the $\mathrm{Co}(\mathrm{OH})_{2} / \mathrm{C}$ and ultra- $\mathrm{Co}(\mathrm{OH})_{2} / \mathrm{C}$ catalysts were composed of a small capacitive semi-circle at the high-frequency region, and a large capacitive semi-circle at the low-frequency region. The smaller impedance of the ultra- $\mathrm{Co}(\mathrm{OH})_{2} / \mathrm{C}$ catalyst (Figure 5b) corresponded to better conductivity. Two peaks existed in the Bode plots of the phase angle versus frequency, as shown in Figure $5 \mathrm{c}$. Thus, the impedance spectra could be fitted by an equivalent circuit model with two time constants, as shown in Figure $5 \mathrm{~d}$. Herein, $R_{\mathrm{S}}$ represents the resistance of the electrolyte between the reference and working electrodes. $R_{f}$ is the resistance of the catalyst itself. $Q$ is the constant phase element in the catalyst. $R_{c t}$ is the electron transfer resistance in the OER process. $C_{\mathrm{dl}}$ is a double-layer capacitance on the catalyst surface.

The values of the equivalent circuit elements were fitted using ZSimpDemo software (3.30d, Ann Arbor, MI, USA). Among of these elements, $\mathrm{Co}(\mathrm{OH})_{2} / \mathrm{C}$ and ultra- $\mathrm{Co}(\mathrm{OH})_{2} / \mathrm{C}$ have $R_{\mathrm{f}}$ values of $4.063 \mathrm{ohm} \mathrm{cm}$ and $3.205 \mathrm{ohm} \mathrm{cm} \mathrm{cm}^{2}$, respectively, and corresponding $R_{\mathrm{ct}}$ values of 8.448 $\mathrm{ohm} \mathrm{cm}^{2}$ and $5.487 \mathrm{ohm} \mathrm{cm}^{2}$. The reduced resistances reveal the smaller obstacle in the OER. Meanwhile, the $0.0173 \mathrm{~F} \mathrm{~cm}^{-2}$ of $C_{\mathrm{dl}}$ of ultra- $\mathrm{Co}(\mathrm{OH})_{2} / \mathrm{C}$ is greater than the $0.0073 \mathrm{~F} \mathrm{~cm}^{-2}$ of $\mathrm{Co}(\mathrm{OH})_{2} / \mathrm{C}$. This result indicates the greater specific surface area and the greater number of active sites of ultra- $\mathrm{Co}(\mathrm{OH})_{2} / \mathrm{C}$ to facilitate the OER. 

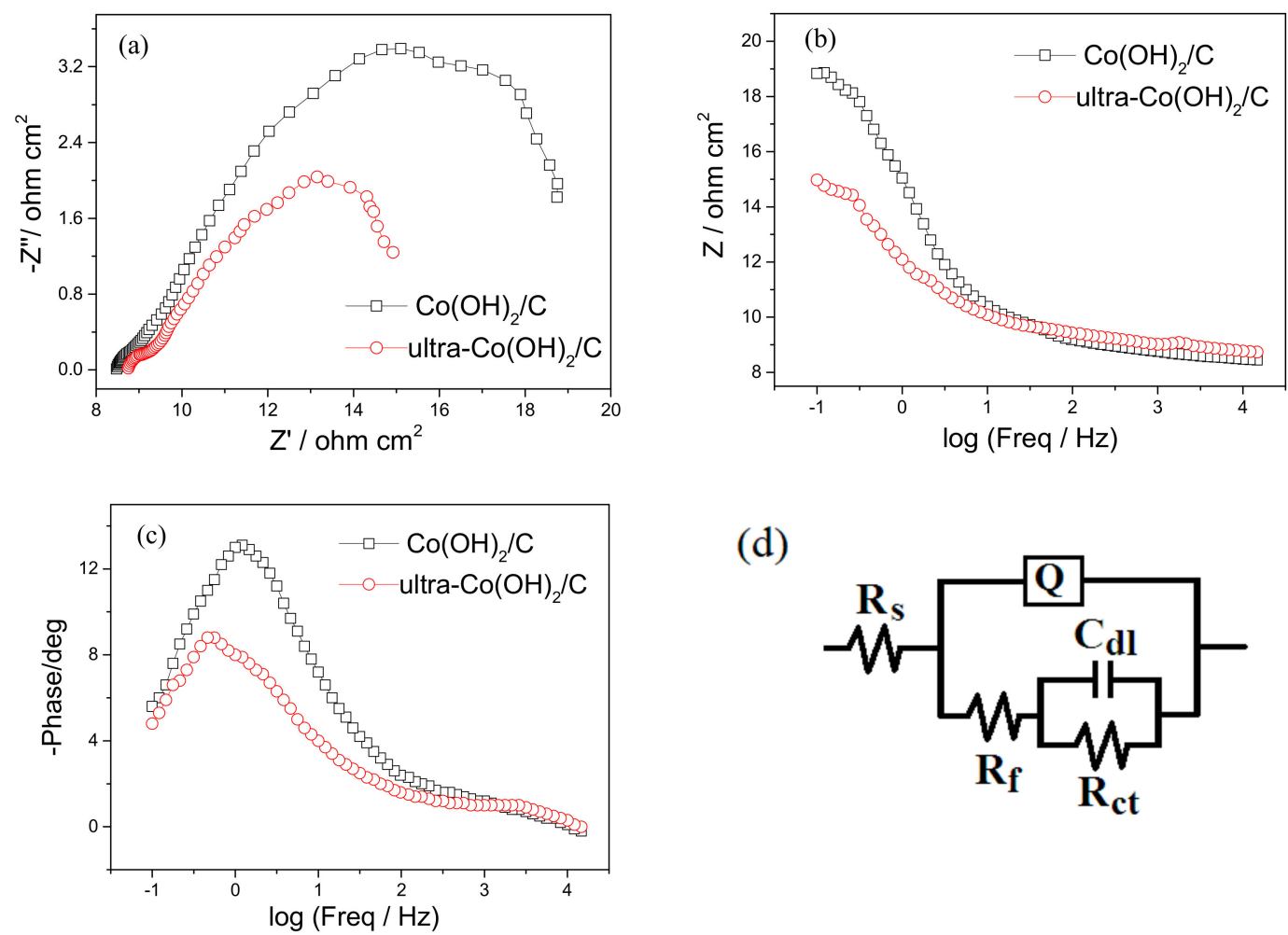

(d)

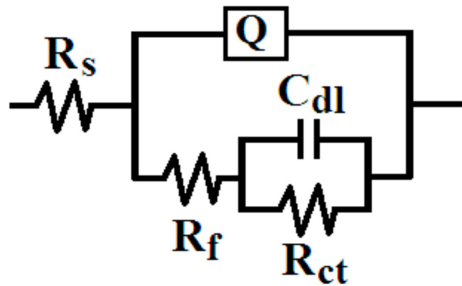

Figure 5. Electrochemical impedance spectra of $\mathrm{Co}(\mathrm{OH})_{2} / \mathrm{C}$ and ultra- $\mathrm{Co}(\mathrm{OH})_{2} / \mathrm{C}$ catalysts, (a) Nyquist curves; (b) Bode plots of $Z$ versus frequency; (c) Bode plots of phase angle versus frequency; and (d) equivalent circuit model.

\section{Conclusions}

An OER catalyst ultra- $\mathrm{Co}(\mathrm{OH})_{2} / \mathrm{C}$ was fabricated by a parallel flow precipitate method with the assistance of ultrasonication. The growth of regular hexagonal crystals of $\mathrm{Co}(\mathrm{OH})_{2}$ was controlled using ultrasonication, and they decreased from approximately $400 \mathrm{~nm}$ to less than $50 \mathrm{~nm}$. The smaller sizes of $\mathrm{Co}(\mathrm{OH})_{2}$ particles exhibit more active sites on the catalyst surface while they promote the formation of a more stable catalytically active film, upon mixing with carbon black. Due to these reasons, the ultra- $\mathrm{Co}(\mathrm{OH})_{2} / \mathrm{C}$ showed better OER catalytic activity with an onset potential of $1.54 \mathrm{~V}$ and a Tafel slope of $18.18 \mathrm{mV} / \mathrm{dec}$, which ensured that the ultra- $\mathrm{Co}(\mathrm{OH})_{2} / \mathrm{C}$ worked well at a more stable and lower potential in the actual OER process. The conductivity of the catalyst was also improved because of the smaller particle of $\mathrm{Co}(\mathrm{OH})_{2}$ and the better incorporation with carbon black. The resistance $R_{\mathrm{f}}$ of the ultra- $\mathrm{Co}(\mathrm{OH})_{2} / \mathrm{C}$ itself and the electron transfer resistance $R_{\mathrm{ct}}$ during the OER were reduced by $21 \%$ and $35 \%$ compared to those observed in the case of $\mathrm{Co}(\mathrm{OH})_{2} / \mathrm{C}$, without the assistance of ultrasonication, leading ultimately to improved catalytic performance in the oxygen evolution reaction.

Author Contributions: Conceptualization, all authors; Methodology and experiment, Y.S., C.G., C.X.; Software, Z.X.; Writing-Original Draft Preparation, Y.S.; Writing-Review \& Editing, C.G.; Funding Acquisition, Y.S., C.G.

Funding: This research was funded by the National Natural Science Fundation of China (NSFC 21805024), the Basic and Frontier Research Program of Chongqing Municipality (cstc2018jcyjAX0461, cstc2015jcyjA50032), the College Students Innovation and Entrepreneurship Training Project of SUSE (No. cx2017017), and the Open Project of Engineering Research Center of New Energy Storage Devices and Applications of Chongqing Municipality (No. KF20170201).

Conflicts of Interest: The authors declare no conflicts of interest. 


\section{References}

1. McCrory, C.C.L.; Jung, S.; Ferrer, I.M.; Chatman, S.M.; Peters, J.C.; Jaramillo, T.F. Benchmarking hydrogen evolving reaction and oxygen evolving reaction electrocatalysts for solar water splitting devices. J. Am. Chem. Soc. 2015, 137, 4347-4357. [CrossRef] [PubMed]

2. Kuai, L.; Geng, J.; Chen, C.; Kan, E.; Liu, Y.; Wang, Q.; Geng, B. A reliable aerosol-spray-assisted approach to produce and optimize amorphous metal oxide catalysts for electrochemical water splitting. Angew. Chem. Int. Ed. 2014, 53, 7547-7551. [CrossRef] [PubMed]

3. Jamesh, M.I.; Sun, X. Recent progress on earth abundant electrocatalysts for oxygen evolution reaction (OER) in alkaline medium to achieve efficient water splitting-A review. J. Power Sources 2018, 400, 31-68. [CrossRef]

4. Liao, P.Q.; Shen, J.Q.; Zhang, J.P. Metal-organic frameworks for electrocatalysis. Coord. Chem. Rev. 2018, 373, $22-48$. [CrossRef]

5. $\quad$ Liang, J.; Wang, Y.Z.; Wang, C.C.; Lu, S.Y. In situ formation of $\mathrm{NiO}$ on $\mathrm{Ni}$ foam prepared with a novel leaven dough method as an outstanding electrocatalyst for oxygen evolution reactions. J. Mater. Chem. A 2016, 4, 9797-9806. [CrossRef]

6. Chen, L.; Dong, X.; Wang, Y.; Xia, Y. Separating hydrogen and oxygen evolution in alkaline water electrolysis using nickel hydroxide. Nat. Commun. 2016, 7, 11741-11748. [CrossRef] [PubMed]

7. Du, P.; Eisenberg, R. Catalysts made of earth-abundant elements (Co, Ni, Fe) for water splitting: Recent progress and future challenges. Energy Environ. Sci. 2012, 5, 6012-6021. [CrossRef]

8. Farid, S.; Ren, S.; Hao, C. MOF-derived metal/carbon materials as oxygen evolution reaction catalysts. Inorg. Chem. Commun. 2018, 94, 57-74. [CrossRef]

9. Ma, Z.; Zhang, Y.; Liu, S.; Xu, W.; Wu, L.; Hsieh, Y.C.; Liu, P.; Zhu, Y.; Sasaki, K.; Renner, J.N.; et al. Reaction mechanism for oxygen evolution on $\mathrm{RuO}_{2}, \mathrm{IrO}_{2}$, and $\mathrm{RuO}_{2} @ \mathrm{IrO}_{2}$ core-shell nanocatalysts. J. Electroanal. Chem. 2018, 819, 296-305. [CrossRef]

10. Sung, M.; Kim, J. Oxygen evolution reaction on Pt sphere and Ir-modified Pt sphere electrodes with porous structures. Int. J. Hydrogen Energy 2018, 43, 2130-2138. [CrossRef]

11. Chen, D.; Chen, C.; Baiyee, Z.M.; Shao, Z.; Ciucci, F. Nonstoichiometric oxides as low-cost and highly-efficient oxygen reduction/evolution catalysts for low-temperature electrochemical devices. Chem. Rev. 2015, 115, 9869-9921. [CrossRef] [PubMed]

12. Gong, M.; Li, Y.; Wang, H.; Liang, Y.; Wu, J.Z.; Zhou, J.; Wang, J.; Regier, T.; Wei, F.; Dai, H. An advanced Ni-Fe layered double hydroxide electrocatalyst for water oxidation. J. Am. Chem. Soc. 2013, 135, 8452-8455. [CrossRef] [PubMed]

13. Liu, P.F.; Yang, S.; Zheng, L.R.; Zhang, B.; Yang, H.G. Electrochemical etching of $\alpha$-cobalt hydroxide for improvement of oxygen evolution reaction. J. Mater. Chem. A 2016, 4, 9578-9584. [CrossRef]

14. Kim, J.; Kim, J.S.; Baik, H.; Kang, K.; Lee, K. Porous $\beta-\mathrm{MnO}_{2}$ nanoplates derived from $\mathrm{MnCO}_{3}$ nanoplates as highly efficient electrocatalysts toward oxygen evolution reaction. RSC Adv. 2016, 6, 26535-26539. [CrossRef]

15. Kanan, M.W.; Nocera, D.G. In situ formation of an oxygen-evolving catalyst in neutral water containing phosphate and $\mathrm{Co}^{2+}$. Science 2008, 321, 1072-1075. [CrossRef] [PubMed]

16. Bediako, D.K.; Lassalle-Kaiser, B.; Surendranath, Y.; Yano, J.; Yachandra, V.K.; Nocera, D.G. Structure-activity correlations in a nickel-borate oxygen evolution catalyst. J. Am. Chem. Soc. 2012, 134, 6801-6809. [CrossRef] [PubMed]

17. Wang, X.X.; Li, T.T.; Zheng, Y.Q. $\mathrm{Co}_{3} \mathrm{O}_{4}$ nanosheet arrays treated by defect engineering for enhanced electrocatalytic water oxidation. Int. J. Hydrogen Energy 2018, 43, 2009-2017. [CrossRef]

18. Xie, T.; Min, J.; Liu, J.; Chen, J.; Fu, D.; Zhang, R.; Zhu, K.; Lei, M. Synthesis of mesoporous $\mathrm{Co}_{3} \mathrm{O}_{4}$ nanosheet-assembled hollow spheres towards efficient electrocatalytic oxygen evolution. J. Alloys Compd. 2018, 754, 72-77. [CrossRef]

19. Zhou, X.; Xia, Z.; Tian, Z.; Ma, Y.; Qu, Y. Ultrathin porous $\mathrm{Co}_{3} \mathrm{O}_{4}$ nanoplates as highly efficient oxygen evolution catalysts. J. Mater. Chem. A 2015, 3, 8107-8114. [CrossRef]

20. Jiang, Y.; Li, X.; Wang, T.; Wang, C. Enhanced electrocatalytic oxygen evolution of $\alpha-\mathrm{Co}(\mathrm{OH})_{2}$ nanosheets on carbon nanotube/polyimide films. Nanoscale 2016, 8, 9667-9675. [CrossRef] [PubMed]

21. Cui, C.; Wang, J.; Luo, Z.; Wang, J.; Li, C.; Li, Z. MOF-mediated synthesis of monodisperse $\mathrm{Co}(\mathrm{OH})_{2}$ flower-like nanosheets for enhanced oxygen evolution reaction. Electrochim. Acta 2018, 273, 327-334. [CrossRef] 
22. Burke, M.S.; Kast, M.G.; Trotochaud, L.; Smith, A.M.; Boettcher, S.W. Cobalt-iron (oxy)hydroxide oxygen evolution electrocatalysts: The role of structure and composition on activity, stability, and mechanism. J. Am. Chem. Soc. 2015, 137, 3638-3648. [CrossRef] [PubMed]

23. Lu, X.; Zhao, C. Electrodeposition of hierarchically structured three-dimensional nickel-iron electrodes for efficient oxygen evolution at high current densities. Nat. Commun. 2015, 6, 6616-6623. [CrossRef] [PubMed]

24. Ruan, J.; Zhao, W.; Wu, L.; Li, X.; Zheng, X.; Ye, Q.; Xu, X.; Wang, F. New insights into graphite paper as electrocatalytic substrate for oxygen evolution reaction. Appl. Surf. Sci. 2017, 396, 1146-1154. [CrossRef]

25. Singh, S.K.; Dhavale, V.M.; Kurungot, S. Surface-tuned $\mathrm{Co}_{3} \mathrm{O}_{4}$ nanoparticles dispersed on nitrogen-doped graphene as an efficient cathode electrocatalyst for mechanical rechargeable zinc-Air battery application. ACS Appl. Mater. Interfaces 2015, 7, 21138-21149. [CrossRef] [PubMed]

26. Lu, X.; Zhao, C. Highly efficient and robust oxygen evolution catalysts achieved by anchoring nanocrystalline cobalt oxides onto mildly oxidized multiwalled carbon nanotubes. J. Mater. Chem. A 2013, 1, 12053-12059. [CrossRef]

27. Leng, X.; Zeng, Q.C.; Wu, K.H.; Gentlea, I.R.; Wang, D.W. Reduction-induced surface amorphization enhances the oxygen evolution activity in $\mathrm{Co}_{3} \mathrm{O}_{4}$. RSC Adv. 2015, 5, 27823-27828. [CrossRef]

28. Zhang, L.; Li, H.; Li, K.; Li, L.; Wei, J.; Feng, L.; Fu, Q. Morphology-controlled fabrication of $\mathrm{Co}_{3} \mathrm{O}_{4}$ nanostructures and their comparative catalytic activity for oxygen evolution reaction. J. Alloys Compd. 2016, 680, 146-154. [CrossRef]

29. Xie, J.; Fang, C.; Zou, J.; Lu, H.; Tian, C.; Han, C.; Zhao, D. In situ ultrasonic formation of $\mathrm{AgBr} / \mathrm{Ag}_{2} \mathrm{CO}_{3}$ nanosheets composite with enhanced visible-driven photocatalytic performance. Mater. Lett. 2016, 170, 62-66. [CrossRef]

30. Xu, Z.; Yu, Y.; Fang, D.; Xu, J.; Liang, J.; Zhou, L. Microwave-ultrasound assisted synthesis of $\beta-\mathrm{FeOOH}$ and its catalytic property in a photo-Fenton-like process. Ultrason. Sonochem. 2015, 27, 287-295. [CrossRef] [PubMed]

31. Khan, N.A.; Jhung, S.H. Synthesis of metal-organic frameworks (MOFs) with microwave or ultrasound: Rapid reaction, phase-selectivity, and size reduction. Coord. Chem. Rev. 2015, 285, 11-23. [CrossRef]

(C) 2018 by the authors. Licensee MDPI, Basel, Switzerland. This article is an open access article distributed under the terms and conditions of the Creative Commons Attribution (CC BY) license (http:// creativecommons.org/licenses/by/4.0/). 